\title{
Narrative Styles and Institutional Isomorphism in South African CEOs' Shareholder Letters
}

\section{Elda du Toit}

Associate Professor, Department of Financial Management, University of Pretoria

(iD https://orcid.org/0000-0001-8386-7969

\section{Leana Esterhuyse}

Senior Lecturer, Department of Financial Intelligence, University of South Africa, Pretoria iD https://orcid.org/0000-0003-0140-7980

\begin{abstract}
Among the most-read corporate documents are chief executive officers' (CEOs') shareholder letters. Using institutional isomorphism as lens, this study examines the extent to which the narrative styles used by South African CEOs in their shareholder letters are similar to the styles used by CEOs at leading international companies. The study also explores the degree to which impression management techniques are present in the South African CEOs' shareholder letters. The study uses DICTION software to conduct a narrative analysis of South African CEOs' shareholder letters for a single financial year, and compares the findings with those drawn from the Craig and Amernic (2018) study of the shareholder letters of CEOs from samples of international Fortune 500 and FTSE 100 companies. The study finds that optimism and realism are the two most-used narrative styles in South African CEOs' shareholder letters, and that these findings are markedly similar to those generated by the Craig and Amernic (2018) study of international companies. The study contributes to the understanding of normative institutional isomorphism in corporate reporting by providing empirical evidence that the narrative styles employed by CEOs of companies in a developing economy with high corporate governance standards conform to the same norms as those of CEOs of large international companies. The study also finds that the South African CEOs' dominant communication styles in the shareholder letters lend themselves to being tools of impression management.
\end{abstract}

\section{Keywords}

corporate communications, narrative styles, CEO shareholder letters, institutional isomorphism, South Africa

\section{Acknowledgement}

The authors thank the anonymous reviewers from the European Academy of Management's 2020 Annual Conference and The African Journal of Information and Communication $(A J I C)$ for their helpful suggestions for improving this article. Any remaining errors are our own. 


\section{Declaration}

The authors declare that they have no competing interests.

\section{Funding}

This research did not receive any specific grant from funding agencies in the public, commercial, or not-for-profit sectors.

DOI: $\underline{\text { https://doi.org/10.23962/10539/31369 }}$

\section{Recommended citation}

Du Toit, E., \& Esterhuyse, L. (2021). Narrative styles and institutional isomorphism in South African CEOs' shareholder letters. The African Journal of Information and Communication (AJIC), 27,1-17. https://doi.org/10.23962/10539/31369

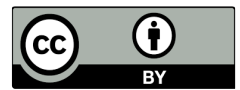

This article is licensed under a Creative Commons Attribution 4.0 International (CC BY 4.0) licence: https://creativecommons.org/licenses/by/4.0

\section{Introduction}

Until recently, the focus of most accounting research was on quantitative information disclosed by companies. However, there is now growing recognition of the importance of qualitative information that captures risks, opportunities, and organisational relationships that quantitative information alone cannot provide (Allee \& DeAngelis, 2015; Arena et al., 2015; Bonsall \& Miller, 2017; González et al., 2021; Laskin, 2018; Mmako, 2016; Mmako \& Jansen van Rensburg, 2017). As a result of the separation of management and ownership in organisations, and the resulting information asymmetry, quality financial and non-financial communication is key to ensuring cohesion and shared understanding between management and stakeholders.

Companies are encouraged to communicate their actions and activities to stakeholders in a transparent way (SEC, 1998; IoDSA, 2009, 2016; JSE, 2013). According to the mimetic and normative institutional isomorphism theory, companies may at first mimic each other in their disclosure style, and then, over time, the disclosure practices become normalised or standardised with little thought given to them (DiMaggio $\&$ Powell, 1983). At the same time, communication styles can be used to influence reactions (Yuthas, Rogers \& Dillard, 2002), manage expectations (Asay et al., 2018a; Laskin, 2018), and/or shape perceptions, according to impression management theory (Allee \& DeAngelis, 2015). The scope for impression management is limited in quantitative corporate reporting (e.g., audited financial statements), but this scope widens considerably in qualitative reporting, where language can be used to shape investors' perceptions (Leung, Parker \& Courtis, 2015; Smith \& Taffler, 2000; Sydserff \& Weetman, 2002). 
Most studies of communication styles in corporate reports focus on companies located in the US, the UK, and other developed economies. This study looks at practices in South Africa, an emerging economy. Applying an institutional isomorphism lens, the study investigates the extent to which the narrative styles deployed by South African chief executive officers (CEOs) in their shareholder letters follow the communication styles of their counterparts, as studied by Craig and Amernic (2018), in Fortune 500 and FTSE 100 international companies. We also examine the extent to which South African CEOs' shareholder letters exhibit the use of impression management techniques. Among other things, this study seeks to answer the call by Allee and DeAngelis (2015) and Laskin (2018) for more research into the narrative styles used by companies in communicating their financial and non-financial results.

South Africa provides a valuable environment for investigation of communication styles in corporate reports, as it is one of the countries at the forefront of the worldwide development of corporate governance codes, with its King Commission developing and regularly updating codes that are integrated into Johannesburg Stock Exchange (JSE) Listings Requirements. According to the World Economic Forum's (WEF) 2019 Global Competitiveness Report, South Africa ranked 26th out of 141 countries for corporate governance, while the US ranked 31st and the UK 13th. The JSE Listings Requirements (JSE, 2019) specify that companies must follow the guidelines in the King IV Code on Corporate Governance (IoDSA, 2016), specifically concerning preparing concise integrated reports that use plain language. In respect of matters of potential institutional isomorphism, South Africa's common law legal system and history under British colonial rule allow for useful exploration of the extent to which its corporate practices exhibit similarities to those of companies with strong Anglo-American ties.

\section{Literature review}

\section{Institutional isomorphism}

Corporate reporting has its earliest roots in agency theory (Jensen \& Meckling, 1976), as the historical purpose of the financial report was to provide information about fiduciary responsibilities. Managers voluntarily disclose information in order to reduce information asymmetry between themselves and owners (shareholders) and to signal their competence and trustworthiness (Jensen \& Meckling, 1976; Spence, 1973). Research has established that investor decision-making is significantly affected by what managers choose to say, as well as how they say it (González et al., 2019). This is seen in verbal (Allee $\&$ DeAngelis, 2015) and written communications (Breton, 2009). In addition to reducing information asymmetry, corporate reporting can also serve legitimising purposes. Companies engage in and report on certain activities, e.g., building schools in the community, in order to obtain approval from society and to retain access to resources (DiMaggio \& Powell, 1983; Deephouse, 1996; Suchman, 1995). Observing this type of reporting by fellow companies can 
also lead to institutional isomorphism, because organisations in similar situations tend to make use of similar structures (De Villiers, Low \& Samkin, 2014; Heugens \& Lander, 2009).

DiMaggio and Powell (1983) identify three types of institutional isomorphism, namely, coercive, mimetic, and normative. In the corporate reporting context, coercive isomorphism occurs when outside pressures, such as those from regulators or stakeholders, force companies to disclose information in a specific way or with a particular emphasis (Areneke, Yusuf \& Kimani, 2019). Mimetic isomorphism typically occurs when there is uncertainty around new reporting practices, which encourages companies to mimic early adopters (De Villiers et al., 2014). Mimetic isomorphism can also be observed when companies follow or mimic others' resistance to new reporting practices (Maroun \& Van Zijl, 2016; Nel \& Esterhuyse, 2019). Normative isomorphism results from companies starting to perceive a certain "way of doing" as the norm and implementing the specific disclosure style because of what they believe is normal or "how it has always been done", or when practices are performed by persons from the same profession or training (DiMaggio \& Powell, 1983; Mizruchi \& Fein, 1999; Suddaby \& Viale, 2011).

An example of institutional isomorphism in the South African reporting context can be found in De Villiers and Alexander (2014), who report finding no meaningful differences between South African and Australian mining companies in the vast majority (29 out of 30 ) of the disclosure patterns in their corporate social responsibility reports-which is evidence of the normative isomorphism that De Villiers and Alexander attribute to the professionalisation of reporting based on common "templates". Furthermore, smaller South African mining companies were found to be disclosing the same amount of environmental information in their reports as were the larger South African mining companies (De Villiers \& Alexander, 2014).

\section{Impression management}

Impression management refers to narrative disclosures that are presented in a way that promotes the image that the company wants to portray (Breton, 2009; Geppert \& Lawrence, 2008; Mmako, 2016). Impression management is connected to legitimacy theory, as legitimacy is achievable only if public impressions of a company's activities are positive (sometimes regardless of actual company performance). Companies can therefore mimic each other to ensure that they obtain legitimacy through disclosures, using impression management. As the need to obtain legitimacy through managing impressions becomes the norm, normative institutional isomorphism ensues. Corporate narrative reporting can therefore be used by companies to manage perceptions and thus maintain legitimacy (Ben-Amar \& Belgacem, 2018; Bozzolan, Cho \& Michelon, 2015; Martins et al., 2019; Melloni, Caglio \& Perego, 2017). 
Impression management theory holds that managers use reports to convey selective information and in a manner that benefits the organisation and themselves, even if not necessarily to the benefit of stakeholders (Allee \& DeAngelis, 2015; Arena et al., 2015; Asay et al., 2018b; Bozzolan et al., 2015; Cho, Roberts \& Patten, 2010; Martins et al., 2019; Leung et al., 2015; Sydserff \& Weetman, 2002; Yuthas et al., 2002). As Cho et al. (2010, p. 432) state, "[...] the more firm performance differs from a desired benchmark, the more management is motivated to manage impressions, and the more likely it is that narrative disclosure will be affected by a self-serving bias."

This self-serving bias (Leung et al., 2015), expressed through impression management tactics in earnings press releases, is rewarded by, for example, equity shares (Arslan-Ayaydin, Boudt \& Thewissen, 2016), which managers can receive if the company that they manage is thought to perform well. Managers also attempt to influence analysts when management issues earnings guidance (for next period's earnings target), and subsequently in press releases and conference calls with analysts, when actual results are announced and discussed in relation to prior guidance and targets (Washburn \& Bromiley, 2014).

Yakis-Douglas et al. (2014) find that managers communicate more to manage market perceptions of merger and acquisition deal announcements, the successful outcome of which will reflect well on the manager. Older CEOs and those with a longer tenure at a company have been found to provide less forward-looking information and to be less optimistic in their quarterly earnings conference calls, indicating that security of tenure plays a role in the communication style of CEOs (Bochkay, Chychyla \& Nanda, 2019). Another impression management tactic is obfuscation, where messages are manipulated or made overly complicated, and certain pieces of information are concealed or omitted through minimal narrative disclosure (Arena et al., 2015; Asay et al., 2018b; Ben-Amar \& Belgacem, 2018; Bonsall \& Miller, 2017; Cho et al., 2010; Goel et al., 2010; Leung et al., 2015; Melloni et al., 2017). This contrasts with calls by users for clear and concise disclosure stretching back as far as the 1960s (Lawrence, 2013). To this end, the US Securities and Exchange Commission (SEC) in 1998 published A Plain English Handbook: How to Create Clear SEC Disclosure Documents, asking companies to use clearly understandable language in their narrative disclosures (SEC, 1998). In South Africa, the Institute of Directors in Southern Africa has requested the same (IoDSA, 2009) from South African corporate report preparers as part of IoDSA's integrated reporting and governance reforms embedded in the various King Codes on Corporate Governance.

\section{CEO shareholder letters as vehicles for impression management}

The individual CEO can frame the narrative that they want to convey to the readership (Dikolli et al., 2020; Mmako, 2016). The chosen narrative could have effects on the readers/shareholders, e.g., consistently using words in the letter that emphasise shareholder value, year after year, has been found to markedly reduce the chances 
of the CEO being dismissed (Shin \& You, 2020). Asay et al. (2018a) find that use of personal pronouns and the presence of a picture of the CEO with the shareholder letter both affect investors' perceptions. Craig and Amernic (2018) call the shareholder letter "staged discourse", as it is written in the CEO's name, in contrast to much of the rest of the integrated annual report. Much thought goes into the shareholder letter, as it should reflect on the results obtained in the year under review and prospects for the future (Aerts \& Yan, 2017; González et al., 2019). The letter is, therefore, an excellent source for determining the use of selective narrative styles. The findings of Asay et al. (2018a), Craig and Amernic (2018), Craig and Brennan (2012), Greiner et al. (2020), and Shin and You (2020) on narrative styles in CEOs' shareholder letters are consistent with impression management theory, i.e., they find that narrative styles are used strategically and that researchers can make certain observations from the language choices employed in these texts.

Most studies on CEO shareholder letters have been performed on companies listed in the US, the UK, and other developed economies. Very little research has been conducted using textual analysis of corporate reports in South Africa. Mmako (2016) and Mmako and Janse van Rensburg (2017) investigate, in CEO shareholder letters of the largest South African companies, the priority (order of presentation) given to certain disclosure items required by integrated reporting, but they do not analyse narrative styles per se. Du Toit (2017) examines readability issues (but not narrative style) in integrated annual reports in South Africa (i.e., not limited to shareholder letters, per se) and establishes that integrated reports that more closely comply with integrated reporting disclosure guidelines are also the reports that tend to use more complex language (thus reducing readability).

\section{Research design and methodology}

The study was guided by two research questions:

- RQ1: To what extent do the narrative styles of South African CEOs' shareholder letters, when compared with the narrative styles in the CEO shareholder letters of top international companies, reflect institutional isomorphism?

- RQ2: To what extent are the narrative styles present in South African CEOs' shareholder letters indicative of impression management techniques?

\section{Source documents}

The South African source documents consisted of CEOs' shareholder letters enclosed in the 2018 integrated annual reports published online by all companies listed in the consumer goods sector and consumer services sector of the JSE's main board. These are the second and third largest industry sectors on the JSE. These integrated reports were the most recent that were available for download when the data was gathered during the course of June 2019. Two integrated reports had no CEO share- 
holder letters, and two of the companies had not yet made an integrated report available online. The final document count totalled $50 \mathrm{CEOs}$ ' shareholder letters with the average length being approximately 2,000 words. (See Appendix for a listing of the 50 companies, each company's industry, each CEO's name and gender, and the word count of each shareholder letter.) Since this was an exploratory study, we considered the sample size of 50 letters from JSE companies to be sufficient for a determination of narrative styles in South African corporate shareholder letters. The sample size was comparable to those used in the Laskin (2018) and Craig and Amernic (2018) studies.

In order to allow for a comparison between the South African shareholder letters and international ones, we drew on the data analysis conducted by Craig and Amernic (2018), who looked at the contents of CEOs' shareholder letters for 91 Fortune 500 companies and 77 FTSE 100 companies, i.e., a total of 168 CEOs' shareholder letters that we regarded as being good representations of the narrative styles of international companies' CEOs.

\section{Narrative analysis}

This study made use of DICTION 7.1.3 software, with its corresponding 31 dictionaries of word lists. DICTION, as developed by Hart (2000), and improved by Hart and Carroll (2013), analyses text for specific linguistic tones or styles. The software classifies text into five master variables or styles—certainty, optimism, activity, realism, and commonality. First, frequencies (word counts as percentages of total words in the document) are determined for each dictionary. Individual dictionary frequencies are then added or subtracted to arrive at the count for each of the five master variables or styles. Each dictionary belongs to one style only (DICTION, n.d.). The output scores are standardised for each dictionary and for the five master variables/styles, enabling direct comparison with the output scores of other texts. We used this feature to answer RQ1, comparing output scores from our sample with those of the international sample analysed by Craig and Amernic (2018). Each of the 50 South African shareholder letters was manually extracted from its integrated report and processed through DICTION.

No textual analysis software is without limitations. Loughran and McDonald (2016), as well as Craig and Amernic (2018), note that some of the words in the DICTION word lists can be misinterpreted in the context of accounting or financial analysis. For example, they indicate that a word such as necessary, listed as a positive word in DICTION, can have a negative connotation in accounting or financial literature. However, we believe that sound classification of the vast majority of the words in the extensive DICTION word lists, and the way in which the master variables are constructed from the individual dictionaries, minimises the effect of some words being misclassified in accounting contexts. Furthermore, we take confidence from the fact that many researchers have relied on DICTION for narrative analyses of corporate 
communications (see, for example, Arena et al., 2015; Arslan-Ayaydin et al., 2016; Bozzolan et al., 2015; Craig \& Brennan, 2012; Craig \& Amernic, 2018; Dikolli et al., 2020; Greiner et al., 2020; Hassan, 2019; Laskin, 2018; Melloni, Caglio \& Perego, 2017; Ober et al., 1999; Yuthas et al., 2002).

\section{Findings and analysis}

To address the first research question (RQ1), we generated our DICTION results across the $50 \mathrm{JSE}$ (South African) documents and compared them to the results that Craig and Amernic (2018) generated from their analysis, also using DICTION, of their aforementioned two sets of CEO shareholder letters: 91 from Fortune 500 companies and 77 from FTSE 100 companies. Table 1 contains the descriptive statistics for the five DICTION master variables (narrative styles) for the $50 \mathrm{JSE}$ shareholder letters, and also provides the mean values found by Craig and Amernic (2018) in their Fortune 500 and FTSE 100 samples.

Table 1 shows that the most prominent narrative style across all three samples is that of optimism with a mean score of 55.43 in the JSE sample and mean scores of 56.54 and 56.12 respectively in the Fortune and FTSE samples analysed by Craig and Amernic (2018). DICTION defines optimism as "[1]anguage endorsing some person, group, concept or event or highlighting their positive entailments" (DICTION, n.d.). As the purpose of the CEO's shareholder letter is to report on the achievements of the company's management during the past year, it is unsurprising that optimism emerges as the most dominant narrative style.

Table 1: Descriptive statistics for the 5 DICTION master variables

\begin{tabular}{|c|c|c|c|c|c|c|}
\hline & \multicolumn{4}{|c|}{$\operatorname{JSE}(n=50)$} & \multirow{2}{*}{$\begin{array}{c}\text { Fortune } \\
\mathbf{5 0 0} \\
\text { mean } \\
(\mathbf{n}=\mathbf{9 1}) \\
(\text { Craig \& } \\
\text { Amernic, } \\
2018)\end{array}$} & \multirow{2}{*}{$\begin{array}{c}\text { FTSE } \\
\mathbf{1 0 0} \\
\text { mean } \\
(\mathbf{n}=\mathbf{7 7}) \\
\text { (Craig \& } \\
\text { Amernic, } \\
2018) \\
\end{array}$} \\
\hline & mean & minimum & maximum & std. deviation & & \\
\hline optimism & 55.43 & 50.18 & 59.68 & 2.69 & 56.54 & 56.12 \\
\hline realism & 52.67 & 48.93 & 56.59 & 2.10 & 54.84 & 54.38 \\
\hline activity & 49.26 & 46.82 & 51.36 & 1.31 & 49.12 & 49.24 \\
\hline commonality & 49.04 & 44.89 & 54.28 & 2.19 & 49.08 & 49.13 \\
\hline certainty & 46.67 & 36.92 & 52.84 & 4.22 & 47.17 & 47.93 \\
\hline
\end{tabular}


The second most popular narrative style identified in the JSE sample, as well as in the Fortune 500 and FTSE 100 samples analysed by Craig and Amernic (2018), is realism, with a mean score of 52.67 in the JSE shareholder letters and means of 54.84 and 54.38, respectively, in the Fortune 500 and FTSE 100 letters. DICTION (n.d.) describes realism as "[1] anguage describing tangible, immediate, recognizable matters that affect people's everyday lives". When a CEO reports, they are indicating, amongst other issues, how the activities of the company have affected its workers, the surrounding community, and other stakeholders. The activities and strategies of the company thus need to be explained in realistic, tangible ways. Although the focus of Craig and Amernic's (2018) study was on CEO hubris, they also conclude that realism as a narrative style is a hallmark of CEOs' shareholder letters.

The activity narrative style was found to have the third-highest mean in all three samples: 49.26 in the JSE sample, 49.12 in the Fortune 500 sample, and 49.24 in the FTSE 100 sample. Activity language is defined, in the DICTION software, as "[1] anguage featuring movement, change, the implementation of ideas and the avoidance of inertia" (DICTION, n.d.). This narrative style is to be expected in a CEO's shareholder letter, as the $\mathrm{CEO}$ is describing how past plans and strategies have been implemented. This style was found to have the lowest standard deviation of the five master variables in the JSE sample. An explanation for this low variation between CEOs could be that almost all CEOs can be expected to write about how previous plans were executed or adapted, as that is arguably core to what "management" entails.

Commonality as narrative style was found to rank fourth in the South African CEOs' letters and in the letters analysed by Craig and Amernic (2018). Commonality showed means of 49.04 in the JSE sample, 49.08 in the Fortune 500 sample, and 49.13 in the FTSE 100 sample. DICTION (n.d.) describes this narrative style as "[1]anguage highlighting the agreed-upon values of a group and rejecting idiosyncratic modes of engagement". It makes sense for CEOs to use this narrative style as they are trying to indicate how the company's strategy execution is achieving the company's shared vision and mission in the longer term. Furthermore, in terms of the agency relationship, the board is appointed by the shareholders and this could spur CEOs on to communicate how the management team's (agents) and her or his values align with those of the shareholders (principal).

The least-used narrative style in our sample and in the samples analysed by Craig and Amernic (2018) was found to be certainty. As seen in Table 1, the means that emerged were 46.67, 47.17 and 47.93, respectively. These scores are well below the fourth-ranked style. DICTION defines the certainty narrative style as "[1]anguage indicating resoluteness, inflexibility, and completeness and a tendency to speak ex-cathedra". When addressing shareholders in the shareholder letter, the CEO must be cognisant of the fact that realities on the ground may force plans to change, and that 
the company should be flexible. Furthermore, the CEO may be attuned to the reality that in many situations, decisions are taken with the best available information, which is not necessarily complete information. Fear of litigation can also dampen the CEO's use of certainty as a narrative style. This narrative style had the largest standard deviation. We assume that this was due to the variations in levels of risk specific to each company.

RQ1 asked to what extent a comparison of the narrative styles in South African and international CEOs' shareholder letters would reflect institutional isomorphism. The combined results from Table 1 lead us to conclude that the narrative styles applied by South African CEOs in their shareholder letters do not meaningfully differ from those of the international company CEOs' letters analysed by Craig and Amernic (2018). If one assumes that most CEOs of large, listed companies complete similar managerial training (e.g., MBA), the similarity in dominant communication styles could be attributable to normative isomorphism (DiMaggio \& Powell, 1983). The fact that the standard of corporate governance in South Africa is judged to be on par with that of some of the world's strongest developed countries (WEF, 2019) contributes to the validity of the finding that normative isomorphism is at work, even when local institutional contexts might be different. Furthermore, the prevailing Anglo-American corporate culture amongst South African CEOs presumably reinforces normative isomorphism and thus contributes to the similarity between South African shareholder letters' narrative styles and the styles found in shareholder letters written by the CEOs of large international companies listed in the US and the UK. We reject mimetic isomorphism as an explanation as there is not a strong novelty aspect to writing a shareholder letter ("new" or "uncertain" conditions are required for mimetic isomorphism). Thousands of examples of shareholder letters are available on companies' websites and they are a standard feature of integrated annual reports.

RQ2 asked to what extent the narrative styles in South African CEOs' shareholder letters could be indicative of the use of impression management techniques. To answer this, we revert to how each of the master variables (styles) is computed in DICTION. The optimism score is a composite of positive words from which negative words relating to blame, hardship, and denial are deducted. A high net score for optimism, which emphasises praise and accomplishments, seems likely to be an indication of impression management in our sample companies. The $\mathrm{CEO}$ is potentially trying to win the favour of the shareholders who must vote at the next annual general meeting on their renewed contract and variable remuneration. DICTION's computation of realism similarly consists of positive scores for, amongst others, familiarity and human interest, from which scores for past concerns and complexity are deducted. A high realism score can also be interpreted as evidence of impression management, in the sense that the $\mathrm{CEO}$ is trying to establish rapport and putting a "human face" on the company. Alternatively, the CEO could be trying to win sympathy from the shareholders, despite the poor performance of the management team. In 
answering the second research question, we therefore conclude that certain narrative styles employed by the CEOs of JSE-listed consumer goods and services companies in their shareholder letters can be understood as evidence of the use of impression management tactics. This should concern readers of shareholder letters and regulators, as excessive impression management can increase client risk and, in turn, audit fees (Dikolli et al., 2020; Greiner et al., 2020), resulting in increased monitoring costs for shareholders.

\section{Conclusions}

This study contributes to the body of literature on normative institutional isomorphism. Our findings indicate that the economic development status of a country does not necessarily mean that its CEOs will employ different narrative styles to those of the CEOs of large international companies based in much richer countries when communicating with shareholders. We propose that good corporate governance standards, cultural commonalities, and standardised business education contribute to normative isomorphism and limit heterogeneity in corporate narrative styles. It is also argued that the South African CEOs'dominant communication styles in the shareholder letters lend themselves to being tools of impression management.

The study also has limitations, with the limitations indicative of ample scope for future research. As an exploratory study, the scope was confined to companies in the consumer goods and consumer services industries, and to a single year of reporting. An investigation of the narrative styles of CEOs of South African companies in other industries would provide useful insights. Observing narrative styles over time would provide insight into the degree to which (if at all) narrative styles evolve as a company grows (or contracts). Textual analysis of additional corporate documents, such as complete integrated annual reports and/or sustainability reports, would also be of value.

\section{References}

Abrahamson, E., \& Amir, E. (1996). The information content of the president's letter to shareholders. Journal of Business Finance and Accounting, 23(8), 1157-1182. https://doi.org/10.1111/j.1468-5957.1996.tb01163.x

Aerts, W., \& Yan, B. (2017). Rhetorical impression management in the letter to shareholders and institutional setting. Accounting, Auditing E' Accountability Journal, 30(2), 404432. https://doi.org/10.1108/AAAJ-01-2015-1916

Alexa, M., \& Zuell, C. (2000). Text analysis software: Commonalities, differences and limitations: The results of a review. Quality and Quantity, 34(3), 299-321. https://0-dx.doi.org.oasis.unisa.ac.za/10.1023/A:1004740203542

Allee, K. D., \& DeAngelis, M. D. (2015). The structure of voluntary disclosure narratives: Evidence from tone dispersion. Journal of Accounting Research, 53(2), 241-274. https://doi.org/10.1111/1475-679X.12072 
Al-Najjar, B., \& Abed, S. (2014). The association between disclosure of forward-looking information and corporate governance mechanisms: Evidence from the UK before the financial crisis period. Managerial Auditing Journal, 29(7), 578-595. https://doi.org/10.1108/MAJ-01-2014-0986

Arena, C., Bozzolan, S., \& Michelon, G. (2015). Environmental reporting: Transparency to stakeholders or stakeholder manipulation? An analysis of disclosure tone and the role of the board of directors. Corporate Social Responsibility and Environmental Management, 22(6), 346-361. https://doi.org/10.1002/csr.1350

Areneke, G., Yusuf, F., \& Kimani, D. (2019). Anglo-American governance adoption in nonAnglo-American settings. Managerial Auditing Journal, 34(4), 482-510. https://doi. org/10.1108/MAJ-12-2017-1733

Arslan-Ayaydin, Ö., Boudt, K., \& Thewissen, J. (2016). Managers set the tone: Equity incentives and the tone of earnings press releases. Journal of Banking and Finance, 72(Supplement), S132-S147. https://doi.org/10.1016/j.jbankfin.2015.10.007

Asay, H. S., Libby, R., \& Rennekamp, K. M. (2018a). Do features that associate managers with a message magnify investors' reactions to narrative disclosures? Accounting, Organizations and Society, 68-69, 1-14. https://doi.org/10.1016/j.aos.2018.02.003

Asay, H. S., Libby, R., \& Rennekamp, K. M. (2018b). Firm performance, reporting goals, and language choices in narrative disclosures. Journal of Accounting and Economics, 65(2-3), 380-398. https://doi.org/10.1016/j.jacceco.2018.02.002

Ben-Amar, W., \& Belgacem, I. (2018). Do socially responsible firms provide more readable disclosures in annual reports? Corporate Social Responsibility and Environmental Management, 25(5), 1009-1018. https://doi.org/10.1002/csr.1517

Bochkay, K., Chychyla, R., \& Nanda, D. (2019). Dynamics of CEO disclosure style. The Accounting Review, 94(4), 103-140. https://doi.org/10.2308/accr-52281

Bonsall, S. B., \& Miller, B. P. (2017). The impact of narrative disclosure readability on bond ratings and the cost of debt. Review of Accounting Studies, 22(2), 608-643. https://doi.org/10.1007/s11142-017-9388-0

Bozzolan, S., Cho, C. H., \& Michelon, G. (2015). Impression management and organizational audiences: The Fiat group case. Journal of Business Ethics, 126(1), 143-165. https:// doi.org/10.1007/s10551-013-1991-9

Breton, G. (2009). From folk-tales to shareholder-tales: Semiotics analysis of the annual report. Society and Business Review, 4(3), 187-201.

https://doi.org/10.1108/17465680910994191

Cho, C. H., Roberts, R. W., \& Patten, D. M. (2010). The language of US corporate environmental disclosure. Accounting, Organizations and Society, 35(4), 431-443. https://doi.org/10.1016/j.aos.2009.10.002

Craig, R. \& Amernic, J. (2018). Are there language markers of hubris in CEO letters to shareholders? Journal of Business Ethics, 149(4), 973-986. https://doi.org/10.1007/s10551-016-3100-3

Craig, R. J., \& Brennan, N. M. (2012). An exploration of the relationship between language choice in CEO letters to shareholders and corporate reputation. Accounting Forum, 36(3), 166-177. https://doi.org/10.1016/j.accfor.2012.02.004

De Villiers, C., \& Alexander, D. (2014). The institutionalisation of corporate social responsibility reporting. The British Accounting Review, 46(2), 198-212. https://doi.org/10.1016/j.bar.2014.03.001 
De Villiers, C., Low, M., \& Samkin, G. (2014). The institutionalisation of mining company sustainability disclosures. Journal of Cleaner Production, 84, 51-58.

https://doi.org/10.1016/j.jclepro.2014.01.089

Deephouse, D. L. (1996). Does isomorphism legitimate? Academy of Management Journal, 39(4), 1024-1039. https://doi.org/10.5465/256722

DICTION. (n.d.). DICTION 7.1 help manual. http://dictionsoftware.com/wp-content/ uploads/2020/09/DICTION-Manual-9-14-20.pdf

Dikolli, S. S., Keusch, T., Mayew, W. J. \& Steffen, T. D. (2020). CEO behavioral integrity, auditor responses, and firm outcomes. The Accounting Review, 95(2), 61-88. https://doi.org/10.2308/accr-52554

DiMaggio, P. J., \& Powell, W. W. (1983). The iron cage revisited: Institutional isomorphism and collective rationality in organizational fields. American Sociological Review, 48(2), 147-160. https://doi.org/10.2307/2095101

Du Toit, E. (2017). The readability of integrated reports. Meditari Accountancy Research, 25(4), 629-653. https://doi.org/10.1108/MEDAR-07-2017-0165

Geppert, J., \& Lawrence, J. E. (2008). Predicting firm reputation through content analysis of shareholders' letter. Corporate Reputation Review, 11(4), 285-307. https://doi-org.uplib.idm.oclc.org/10.1057/crr.2008.32

Goel, S., Gangolly, J., Faerman, S. R., \& Uzuner, O. (2010). Can linguistic predictors detect fraudulent financial filings? Journal of Emerging Technologies in Accounting, 7(1), 2546. https://doi.org/10.2308/jeta.2010.7.1.25

González, M., Guzmán, A., Téllez, D. F., \& Trujillo, M. A. (2021). What you say and how you say it: Information disclosure in Latin American firms. Journal of Business Research, 127, 427-443. https://doi.org/10.1016/j.jbusres.2019.05.014

Greiner, A. J., Patelli, L., \& Pedrini, M. (2020). Characteristics of managerial tone priced by auditors: Evidence based on annual letters to shareholders of large U.S. Firms. Auditing: A Journal of Practice E' Theory, 39(2), 139-161.

https://doi.org/10.2308/ajpt-52594

Hart, R., \& Carroll, C. (2013). DICTION 7: The text analyses program. Digitext.

Hart, R. (2000). DICTION 5.0: The text analysis program. Sage.

Hassan, A. (2019). Verbal tones in sustainability assurance statements. An empirical exploration of explanatory factors. Sustainability Accounting, Management and Policy Journal, 10(3), 427-450. https://doi.org/10.1108/SAMPJ-06-2017-0051

Heugens, P. P., \& Lander, M. W. (2009). Structure! Agency! (and other quarrels): A metaanalysis of institutional theories of organization. Academy of Management Journal, 52(1), 61-85. https://doi.org/10.5465/AMJ.2009.36461835

Institute of Directors in Southern Africa (IoDSA). (2009). King report on governance for South Africa (King III).

IoDSA. (2016). King IV report on corporate governance for South Africa 2016.

Jensen, M. C., \& Meckling, W. H. (1976). Theory of the firm: Managerial behavior, agency costs and ownership structure. Journal of Financial Economics, 3(4), 305-360.

https://doi.org/10.1016/0304-405X(76)90026-X

Johannesburg Stock Exchange (JSE). (2019). JSE Limited Listings Requirements.

Khlif, H. (2016). Hofstede's cultural dimensions in accounting research: A review. Meditari Accountancy Research, 24(4), 545-573.

https://doi.org/10.1108/MEDAR-02-2016-0041 
Laskin, A. V. (2018). The narrative strategies of winners and losers: Analyzing annual reports of publicly traded corporations. International Journal of Business Communication, 55(3), 338-356. https://doi.org/10.1177/2329488418780221

Lawrence, A. (2013). Individual investors and financial disclosure. Journal of Accounting and Economics, 56(1), 130-147. https://doi.org/10.1016/j.jacceco.2013.05.001

Leung, S., Parker, L., \& Courtis, J. (2015). Impression management through minimal narrative disclosure in annual reports. The British Accounting Review, 47(3), 275-289. https:// doi.org/10.1016/j.bar.2015.04.002

Loughran, T., \& McDonald, B. (2016). Textual analysis in accounting and finance: A survey. Journal of Accounting Research, 54(4), 1187-1230.

https://doi.org/10.1111/1475-679X.12123

Maroun, W., \& Van Zijl, W. (2016). Isomorphism and resistance in implementing IFRS 10 and IFRS 12. The British Accounting Review, 48(2), 220-239. https://doi.org/10.1016/j.bar.2015.07.003

Martins, A., Gomes, D., Oliveira, L., \& Ribeiro, J. L. (2019). Telling a success story through the president's letter. Qualitative Research in Accounting \& Management, 16(3), 403433. https://doi.org/10.1108/QRAM-03-2018-0018

Melloni, G., Caglio, A., \& Perego, P. (2017). Saying more with less? Disclosure conciseness, completeness and balance in integrated reports. Journal of Accounting and Public Policy, 36(3), 220-238. https://doi.org/10.1016/j.jaccpubpol.2017.03.001

Mizruchi, M. S., \& Fein, L. C. (1999). The social construction of organizational knowledge: A study of the uses of coercive, mimetic, and normative isomorphism. Administrative Science Quarterly, 44(4), 653-683. https://doi-org.uplib.idm.oclc.org/10.2307/2667051

Mmako, N., \& Jansen van Rensburg, M. (2017). Towards integrated reporting: The inclusion of content elements of an integrated annual report in the chairmen's statements of JSE-listed companies. South African Journal of Business Management, 48(1), 45-54. https://doi.org/10.4102/sajbm.v48i1.19

Mmako, N. (2016). The chairperson's statement: Understanding prioritisation of discretionary disclosures by Johannesburg Security Exchange listed companies. Journal of Contemporary Management, 13(1), 385-408. https://hdl.handle.net/10520/ EJC192862

Nel, G., \& Esterhuyse, L. (2019). Corporate websites as a stakeholder communication channel: A comparison of JSE-listed companies' websites over time. Journal of Global Business and Technology, 15(1), 34-46.

Ober, S., Zhao, J. J., Davis, R., \& Alexander, M. W. (1999). Telling it like it is: The use of certainty in public business discourse. The Journal of Business Communication (1973), 36(3), 280-296. https://doi-org.uplib.idm.oclc.org/10.1177/002194369903600304

Securities and Exchange Commission (SEC). (1998). A plain English handbook: How to create clear SEC disclosure documents. http://www.sec.gov/pdf/handbook.pdf

Shin, T., \& You, J. (2020). Changing words: How temporal consistency in a CEO's use of language toward shareholders and stakeholders affects CEO dismissal. Corporate Governance: An International Review, 28(1), 47-68. https://doi.org/10.1111/ corg. 12302

Smith, M., \& Taffler, R. J. (2000). The chairman's statement - A content analysis of discretionary narrative disclosures. Accounting, Auditing and Accountability Journal, 13(5), 624-647. https://doi.org/10.1108/09513570010353738 
Spence, M. (1973). Job market signaling. The Quarterly Journal of Economics, 87(3), 355-374. https://doi.org/10.2307/1882010

Suchman, M. C. (1995). Managing legitimacy: Strategic and institutional approaches. Academy of Management Review, 20(3), 571-610. https://doi.org/10.5465/AMR.1995.9508080331

Suddaby, R., \& Viale, T. (2011). Professionals and field-level change: Institutional work and the professional project. Current Sociology, 59(4), 423-442. https://doi.org/10.1177/0011392111402586

Sydserff, R., \& Weetman, P. (2002). Developments in content analysis: A transitivity index and DICTION scores. Accounting, Auditing and Accountability Journal, 15(4), $523-$ 545. https://doi-org.uplib.idm.oclc.org/10.1108/09513570210440586

Washburn, M., \& Bromiley, P. (2014). Managers and analysts: An examination of mutual influence. Academy of Management Journal, 57(3), 849-868. https://doi.org/10.5465/amj.2011.0420

World Economic Forum (WEF). (2019). The global competitiveness report 2019.

Yakis-Douglas,B.,Angwin,D.,Meadows,M.\&Ahn,K.(2014). Voluntary disclosures as a form of impression management to reduce evaluative uncertainty during M\&A. Academy of Management Proceedings, 2014(1), 15879. https://doi.org/10.5465/ambpp.2014.1

Yuthas, K., Rogers, R., \& Dillard, J. F. (2002). Communicative action and corporate annual reports. Journal of Business Ethics, 41(1/2), 141-157.

https://doi.org/10.1023/A:1021314626311 
Appendix: South African sample for the study

\begin{tabular}{|c|c|c|c|c|}
\hline Company name & CEO & $\begin{array}{l}\text { CEO's } \\
\text { gender }\end{array}$ & Industry & $\begin{array}{l}\text { CEO let- } \\
\text { ter's word } \\
\text { count }\end{array}$ \\
\hline ADvTECH Ltd. & Roy Douglas & Male & Consumer services & 2,141 \\
\hline $\begin{array}{c}\text { Anheuser-Busch InBev } \\
\text { SA/NV }\end{array}$ & Carlos Brito & Male & Consumer goods & 2,407 \\
\hline Astral Foods Ltd. & Chris Schutte & Male & Consumer goods & 5,413 \\
\hline AVI Ltd. & Simon Crutchley & Male & Consumer goods & 2,806 \\
\hline Bid Corporation Limited & Bernard Berson & Male & Consumer services & 3,385 \\
\hline $\begin{array}{l}\text { British American Tobac- } \\
\text { co plc }\end{array}$ & Nicandro Durante & Male & Consumer goods & 1,112 \\
\hline Cashbuild Ltd. & Werner de Jager & Male & Consumer services & 1,117 \\
\hline Clicks Ltd. & David Kneale & Male & Consumer services & 2,384 \\
\hline Clover Industries Ltd. & Johann Vorster & Male & Consumer goods & 1,819 \\
\hline Comair Ltd. & Erik Venter & Male & Consumer services & 4,062 \\
\hline $\begin{array}{l}\text { Combined Motor Hold- } \\
\text { ings Ltd. }\end{array}$ & JD McIntosh & Male & Consumer services & 2,512 \\
\hline Crookes Brothers Ltd. & Guy Clarke & Male & Consumer goods & 1,023 \\
\hline Curro Ltd. & Andries Greyling & Male & Consumer services & 649 \\
\hline Dischem Ltd. & $\begin{array}{l}\text { Ivan Leon Saltz- } \\
\text { man }\end{array}$ & Male & Consumer services & 1,759 \\
\hline Famous Brands Ltd. & Darren Hele & Male & Consumer services & 2,245 \\
\hline $\begin{array}{l}\text { HomeChoice Holdings } \\
\text { Ltd. }\end{array}$ & Gregoire Lartigue & Male & Consumer services & 2,074 \\
\hline $\begin{array}{l}\text { Hosken Passenger Logis- } \\
\text { tics and Rail Ltd. }\end{array}$ & Francois Meyer & Male & Consumer services & 906 \\
\hline Italtile Ltd. & Jan Potgieter & Male & Consumer services & 3,481 \\
\hline Kaap Agri Bedryf Ltd. & Sean Walsh & Male & Consumer services & 1,257 \\
\hline Lewis Group Ltd. & Johan Enslin & Male & Consumer services & 1,065 \\
\hline Libstar Holdings Ltd. & $\begin{array}{l}\text { Andries van Rens- } \\
\text { burg }\end{array}$ & Male & Consumer goods & 2,349 \\
\hline Massmart Holdings Ltd. & Guy Hayward & Male & Consumer services & 4,112 \\
\hline Metair Investments Ltd. & Theo Loock & Male & Consumer goods & 1,902 \\
\hline Mr Price Group Ltd. & Stuart Bird & Male & Consumer services & 698 \\
\hline Naspers Ltd. & Bob van Dijk & Male & Consumer services & 1,851 \\
\hline Northam Platinum Ltd. & Paul Dunne & Male & Consumer services & 1,675 \\
\hline Oceana Group Ltd. & Imraan Soomra & Male & Consumer goods & 2,382 \\
\hline Pepkor Holdings Ltd. & Leon Lourens & Male & Consumer services & 1,276 \\
\hline $\begin{array}{c}\text { Phumelela Gaming \& } \\
\text { Leisure Ltd. }\end{array}$ & John Stuart & Male & Consumer services & 1,844 \\
\hline
\end{tabular}




\begin{tabular}{|c|c|c|c|c|}
\hline Pick n Pay Stores Ltd. & Richard Brasher & Male & Consumer services & 2,113 \\
\hline Pioneer Foods Ltd. & Tertius Carstens & Male & Consumer goods & 1,651 \\
\hline $\begin{array}{c}\text { Premier Fishing and } \\
\text { Brands Ltd. }\end{array}$ & $\begin{array}{c}\text { Mogamat Samier } \\
\text { Saban }\end{array}$ & Male & Consumer goods & 1,091 \\
\hline Quantum Foods Ltd. & Hendrik Lourens & Male & Consumer goods & 2,115 \\
\hline RCL Foods Ltd. & Miles Dally & Male & Consumer goods & 4,071 \\
\hline $\begin{array}{l}\text { Rex Trueform Group } \\
\text { Ltd. }\end{array}$ & $\begin{array}{c}\text { Catherine Rad- } \\
\text { owsky }\end{array}$ & Female & Consumer services & 855 \\
\hline Rhodes Food Group Ltd. & Bruce Henderson & Male & Consumer goods & 1,217 \\
\hline Sea Harvest Group Ltd. & Felix Ratheb & Male & Consumer goods & 1,272 \\
\hline $\begin{array}{l}\text { Seardel Investment Corp. } \\
\text { Ltd. }\end{array}$ & André van der Veen & Male & Consumer services & 867 \\
\hline Shoprite Holdings Ltd. & Pieter Engelbrecht & Male & Consumer services & 1,034 \\
\hline Spur Corporation Ltd. & Pierre van Tonder & Male & Consumer services & 2,811 \\
\hline Stadio Holdings Ltd. & $\begin{array}{l}\text { Chris van der } \\
\text { Merwe }\end{array}$ & Male & Consumer services & 537 \\
\hline $\begin{array}{c}\text { Steinhoff International } \\
\text { NV }\end{array}$ & Louis du Preez & Male & Consumer goods & 2,926 \\
\hline Sun International Ltd. & Anthony Leeming & Male & Consumer services & 3,056 \\
\hline Taste Holdings Ltd. & Tyrone Moodley & Male & Consumer services & 2,090 \\
\hline The Foschini Group Ltd. & Doug Murray & Male & Consumer services & 2,002 \\
\hline The Spar Group Ltd. & Graham O'Connor & Male & Consumer services & 1,931 \\
\hline Tiger Brands Ltd. & $\begin{array}{c}\text { Lawrence Mac- } \\
\text { Dougall } \\
\end{array}$ & Male & Consumer goods & 2,096 \\
\hline Truworths Ltd. & Michael Mark & Male & Consumer services & 2,290 \\
\hline Tsogo Sun Ltd. & Jacques Booysen & Male & Consumer services & 2,477 \\
\hline Vivo Energy plc & $\begin{array}{c}\text { Christian Cham- } \\
\text { mas }\end{array}$ & Male & Consumer services & 1,184 \\
\hline $\begin{array}{l}\text { Woolworths Holdings } \\
\text { Ltd. }\end{array}$ & Ian Moir & Male & Consumer services & 2,388 \\
\hline
\end{tabular}

